\title{
Biodiversity and community structure of the mega-epibenthos in the Magellan region (South America)*
}

\author{
JULIAN GUTT, ELISABETH HELSEN, WOLF ARNTZ and ALEXANDER BUSCHMANN \\ Alfred Wegener Institute for Polar and Marine Research, Columbusstrasse, D - 27568 Bremerhaven, Germany. \\ E-mail: jgutt@awi-bremerhaven.de
}

\begin{abstract}
SUMMARY: Epibenthic communites have been investigated at 55 stations in the Magellan region by underwater photography at water depths between 15 and $430 \mathrm{~m}$. Five species assemblages were identified of which the two shallow and the two deep ones in the channel system differed considerably in abundance, number of taxa, diversity and species composition. The dominant systematic group of the shallow assemblages were ascidians. In one of these assemblages decapod crustaceans, in the other mainly sessile suspension feeders e.g. sponges, anthozoans and bryozoans were the characteristic taxa. In the deeper assemblages echinoderms were most abundant. The fifth assemblage, consisting of several offshore stations south of the eastern entrance of the Beagle, was more similar to the shallow stations in the channel system in terms of dominant life forms. Various hypotheses were confirmed or rejected: The benthos at the deeper stations in the channel system was not more homogeneous than at the shallow stations. At both the channel and the offshore stations filter feeders were most dominant whereas at the bottom of the channels deposit feeders were more abundant. Differences between the wide Straits of Magellan and the narrow and steep Beagle Channel were not very distinct. The benthic assemblages inside the channel system did not differ considerably from the assemblage outside the channel system with the exception of the stations close to the continental slope of the Atlantic. Differences due to Pacific or Atlantic influences were not recognisable. The biological patterns could best be explained by the environmental parameters water depth, occurrence of soft sediment and biogenic debris.
\end{abstract}

Key words: Mega-epibenthos, Magellan region, community analysis, biodiversity.

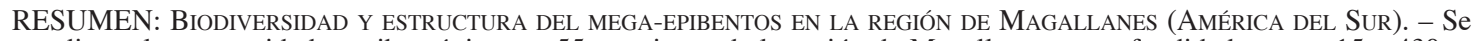
estudiaron las comunidades epibentónicas en 55 estaciones de la región de Magallanes en profundidades entre 15 y $430 \mathrm{~m}$ mediante fotografía subacuática. Se identificaron cinco comunidades distintas. Las dos comunidades someras y las dos profundas en el sistema de canales revelaron diferencias considerables en lo que se refiere a abundancia, número de taxones, diversidad y composición específica. Las ascidias predominaron en las comunidades someras. En una de ellas, los crustáceos decápodos fueron el taxón característico mientras en la otra lo fueron los suspensívoros sésiles tales como esponjas, antozoos o briozoos. En las comunidades de mayor profundidad los equinodermos fueron el grupo más notable. La quinta comunidad, compuesta por varias estaciones situadas al sur de la entrada este del Canal del Beagle, resultó ser muy parecida a la de las estaciones someras en el sistema de canales en términos de formas de vida dominantes. Se aceptaron o rechazaron varias hipótesis. El bentos en las estaciones más profundas del sistema de canales no se mostró más homogéneo que en las estaciones someras. Tanto en las estaciones cercanas como en las estaciones fuera de la costa predominaron los suspensívoros, mientras que los detritívoros fueron el grupo dominante en el fondo de los canales. No se detectaron diferencias muy marcadas entre el Estrecho de Magallanes, de configuración ancha, y el Canal del Beagle de forma estrecha y pendiente fuerte. Con excepción de las estaciones cercanas al talud continental atlántico, las comunidades fuera del sistema de canales no se distinguieron mucho de las de dentro. No se evidenciaron diferencias faunísticas causadas por influencia pacífica o atlántica. Los patrones biológicos se pueden explicar mejor por los parámetros ambientales profundidad del agua, presencia de sedimentos blandos y escombros biogénicos.

Palabras clave: mega-epibentos, región magallánica, análisis de comunidades, biodiversidad.

This is AWI conntr. no. 1750

*Accepted November 6, 1998. 


\section{INTRODUCTION}

The objective of this study was a faunistic-ecological survey of the mega-epibenthos in deeper waters of the Straits of Magellan, the Beagle Channel, and the channel system southeast of Tierra del Fuego. Contrary to a number of shallow-water $(<15 \mathrm{~m})$ studies of a primarily ecological character (e.g., Ojeda and Santelices, 1984; Dayton, 1985; Castilla, 1985) most former benthic investigations in this area centred around either taxonomic questions (e.g., Retamal, 1973; 1974; Jaramillo, 1981; Moyano, 1992; Sarà, 1992) or focused on single economically interesting species (e.g., Guzmán et al., 1987; Vinuesa et al., 1989; Vinuesa, 1991). In contrast, in this investigation we tried to consider the mega-epibenthos as a whole. Thus the results can contribute to understanding whether certain ecological paradigms can, or cannot, be confirmed for this area. They can also serve as a baseline for a comprehensive coastal management including aspects of nature conservation, much more so since this study was embedded in the "Joint "Victor Hensen' Magellan Campaign", in which many different compartments of the ecosystem were investigated with similar objectives.

With this backgound in mind sampling sites with different characteristics were chosen in order to check the following ecological hypotheses:

- In shallow areas the benthos is more heterogeneous due to strongly varying environmental factors than in deeper areas, where the environment is supposed to be more stable.

- At slopes inside the channel system and offshore as well as in shallow waters close to the coast, filter feeders are supported by the environmental conditions, e.g. horizontal transport of particulate organic matter, whereas at the bottom of the channels sediment feeders are favoured due to a higher amount of deposited detritus.

- The benthos of the wide Straits of Magellan is significantly different compared with the benthic communities in the narrow and steep Beagle Channel.

- The benthos inside the channel system differs from that which is more exposed to the open oceans because the (partly deep) channel system is separated from the continental coast by shallow sills.

- The influence of either Pacific or Atlantic faunal elements is recognizable in different parts of the investigation area.

The following aspects were analyzed in detail:

1. Identification and quantification of all megaepibenthic organisms as accurately as possible.
2. Classification of different benthic communities according to available physical (environmental) parameters which may explain the biological pattern.

3. Characterization of species assemblages in terms of abundance and composition of the taxa, key species, and their biodiversity.

Due to this approach underwater photography was used because it provides quantitative data mainly for sessile animals. It covers sampling sites of sufficient extension even for the large, and therefore less abundant, taxa. In addition the biological results from different sites are directly comparable because sampling is not biased by sediment characteristics.

\section{MATERIAL AND METHODS}

\section{Field work}

The investigation was carried out during the "Joint 'Victor Hensen' Magellan Campaign" during austral summer 1994 and during the expedition ANT XIII/4 with R/V "Polarstern" in May 1996. A 70 mm underwater camera (Hasselblad 500EL/M with two Metz Mecablitz 40 CT4 flashes) was deployed at 55 stations at water depths between 15 and 430m (Fig. 1; Table 1); for exact position of stations cf. Table 13 (Annex) in Arntz and Gorny (1996) and Arntz et al.

TABLE 1. - Station list according to station clusters; upper part: stations used for community analysis, lower part: additional stations classified according to firstly calculated key species. For positions of A-F see Fig. 2.

\begin{tabular}{|c|c|c|c|c|}
\hline SNE & $\mathrm{S}$ & $\begin{array}{c}\text { clusters } \\
\text { DE } 1\end{array}$ & DE 2 & OS \\
\hline $\begin{array}{l}921 \\
964 \\
1163 \\
1167 \\
1193 \\
1208 \\
1224\end{array}$ & $\begin{array}{r}\mathrm{A} \\
\mathrm{B} \\
890 \\
917 \\
927 \\
951 \\
957 \\
959 \\
968 \\
1177 \\
1205 \\
1217 \\
1219 \\
1276 \\
1293 \\
1299 \\
1312\end{array}$ & $\begin{array}{r}C \\
D \\
E \\
1125 \\
1311\end{array}$ & $\begin{array}{r}F \\
1078 \\
1079 \\
1985\end{array}$ & $\begin{array}{l}110 \mathrm{~A} \\
110 \mathrm{~B} \\
112 \mathrm{~A} \\
112 \mathrm{~B} \\
113 \mathrm{~A} \\
113 \mathrm{~B} \\
116 \mathrm{~A} \\
116 \mathrm{~B}\end{array}$ \\
\hline $\begin{array}{l}1229 \\
1239 \\
1243 \\
1284 \\
1285\end{array}$ & $\begin{array}{r}880 \\
1285\end{array}$ & $\begin{array}{r}879 \\
1090\end{array}$ & 1106 & \\
\hline
\end{tabular}



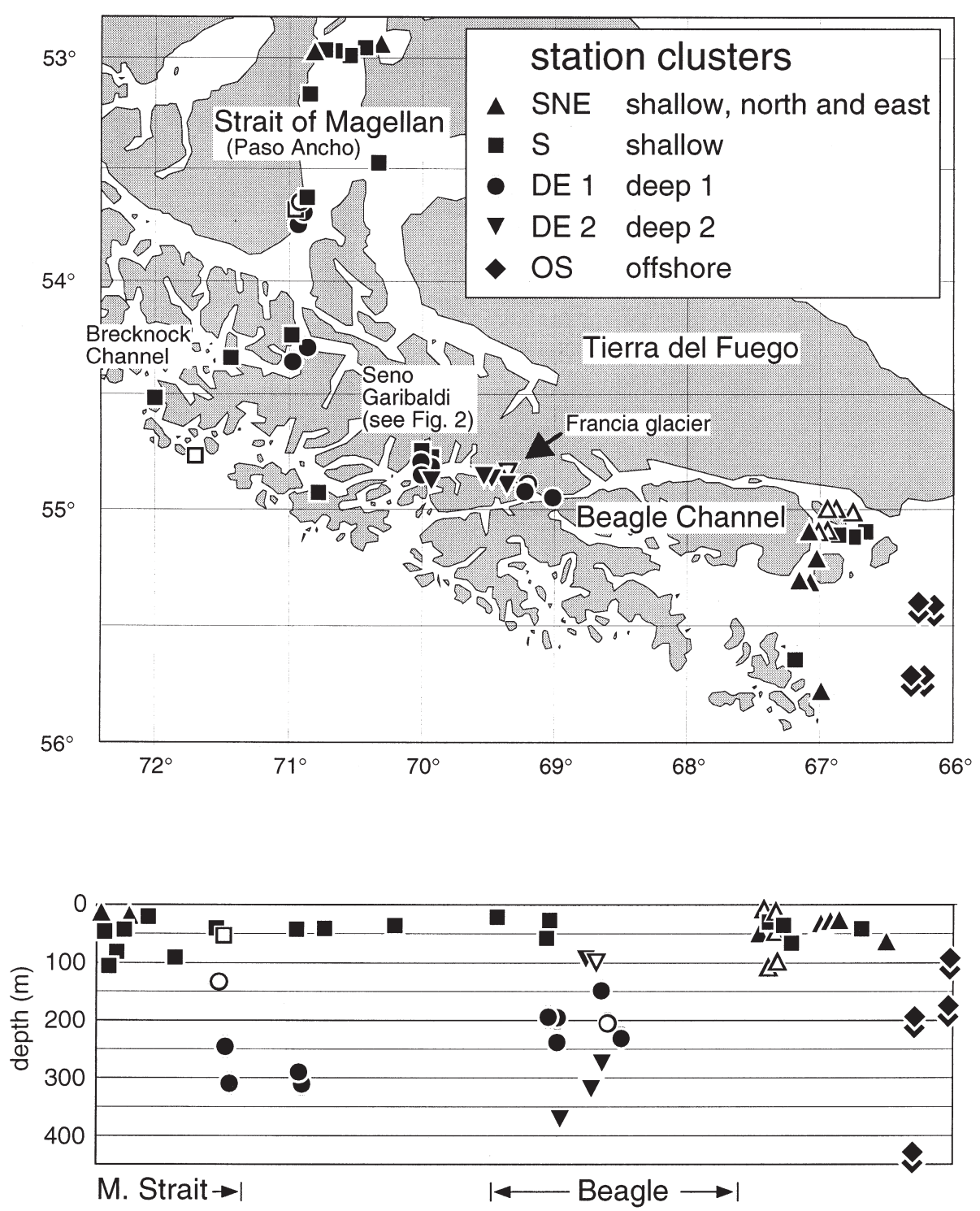

FIG. 1. - Station map. In the lower part stations are aligned (from left to right) along a transect starting at the northern part of Paso Ancho (Straits of Magellan) through the channel system east of Tierra del Fuego into the Beagle Channel and further east to the offshore stations south of the eastern mouth of the Beagle. Symbols represent different clusters according to cluster analysis. Open symbols indicate stations classified only by key taxa.

(1997). The camera was triggered at a constant distance above the seafloor. The optical resolution was $0.3 \mathrm{~mm}$ using a Kodak Ektachrome 64 film. The size of the area vertically photographed $\left(0.9 \mathrm{~m}^{2}+/-3 \%\right.$ per frame) was calculated by reference to two stations where the trigger weight was photographed and served as a spatial scale. The photographs from the original sampling sites 1030, 1035, 1041, 1057, and 1058 were recombined to a total of six stations (A-F) according to water depth along a transect starting inside the Seno Garibaldi at $70 \mathrm{~m}$, crossing two sills at approx. $15 \mathrm{~m}$ and $190 \mathrm{~m}$ depth, and ending in the centre of the Beagle Channel at 370m water depth (Fig. 2). The offshore sites sampled during the expe- dition ANT XIII/4 (original stations 110, 112, 113, and 116) were split into four pairs of pseudo-replicates (total of eight stations: 110A, 110B, ..., 116A, 116B). From 30 stations 40 photographs each, and from another 15 stations slightly less photographs (35-39 each), were used for the community analysis and diversity study. The 1753 photographs represent an area of $1577.7 \mathrm{~m}^{2}$ of seafloor. The community structure at an additional 10 stations with clearly less than 40 photographs or with photographs of low quality, e.g. due to much suspended matter in the water column, was classified on the basis of key taxa determined beforehand for the material analyzed in more detail. 


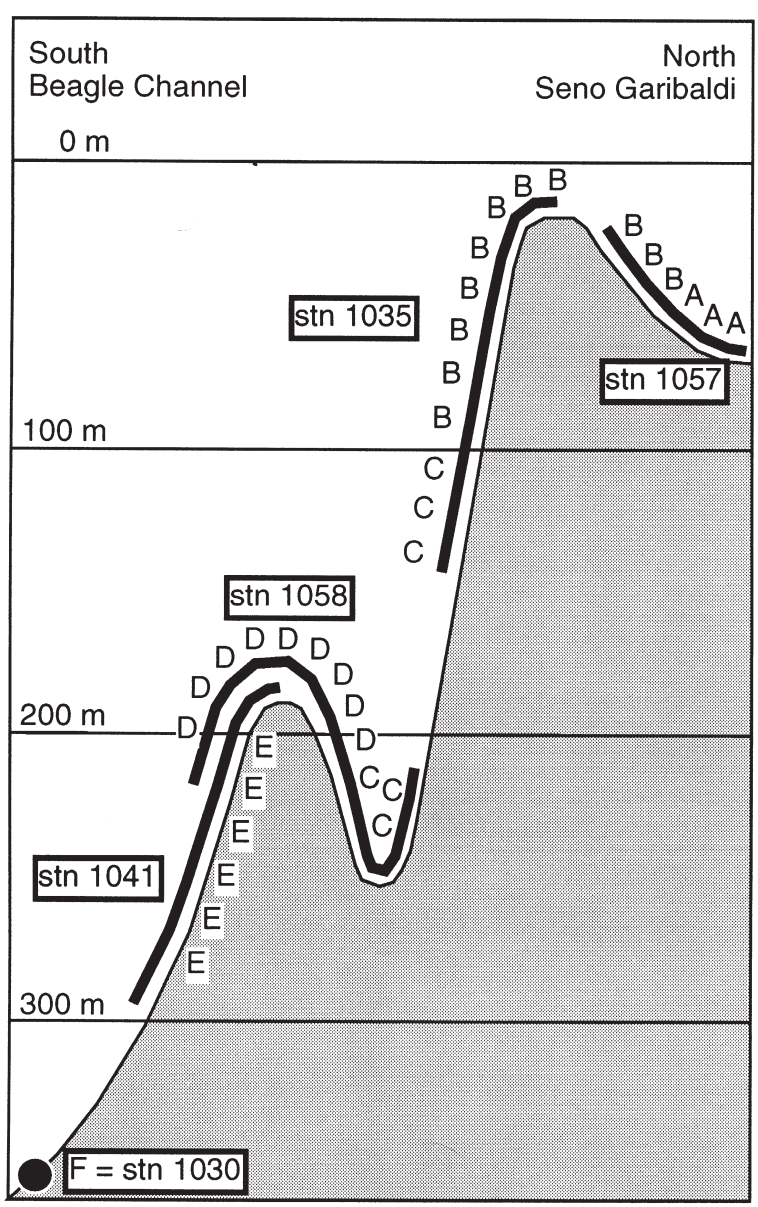

FIG. 2. - Photographic transects at the entrance of the Seno Garibaldi with original station numbers and rearranged stations (A-F) according to water depth and position.

\section{Identification and counting}

Identification was supported by experts: S. Cornejo, C. Dahm, C. Jara, H. I. Moyano, E. Mutschke, M. Pansini, C. Ríos, I. S. Wehrtmann. The "taxon" Synascidian(s) does not refer to the systematic classification, it describes a life form which occurs in different families of ascidians which also include solitary species.

With few exceptions all photographed organisms $>0.5 \mathrm{~cm}$ were counted. Small encrusting forms were not considered. For most bryozoans, all algae, and the taxon Polychaeta sp. 2 the cover of the seafloor was determined in percent to obtain a value roughly equivalent to the abundances of other taxa. For other colonial taxa, e.g. hydrozoans and synascidians, the colonies were counted as one individual. These values were treated in further calculations as true abundances in order not to exclude any life forms only due to the fact that single organisms cannot be counted. Infaunal species were considered when part of their body was visible. Abundances were standardized as numbers per $10 \mathrm{~m}^{2}$.

\section{Community analysis and key taxa}

Taxa which occurred at less than three stations were not considered because the common presence of two extremely rare taxa -which is due to chancewould lead to an erroneous high similarity between the taxon clusters. Only organisms identified to the species or genus level were analyzed. Double square root transformation was used (45 stations, 125 taxa) because, in combination with the Bray-Curtis index (Bray and Curtis, 1957), the similarity coefficient is invariant to a scale change (Field et al., 1982). The results for the stations are shown in a Multidimensional Scaling (MDS) plot (Fig. 3) as a method of ordination (Field et al., 1982) which shows the similarities of all stations to each other on a two-dimensional scale. The result from the classification by a cluster analysis were superimposed in the MDS. The order and grouping of the taxa resulting from the cluster analysis (dendrogram) was used for their arrangement in the community table (Table 2).

Key taxa which served as discriminators for the classification of stations were determined by a modified Bray-Curtis index (Clarke, 1993). Good discriminators perform a high contribution to the average dissimilarity between each station cluster and all other stations $\left(\mathrm{d}_{\mathrm{i}}\right)$ and a high quotient between $\mathrm{d}_{\mathrm{i}}$ and its standard deviation (SD).

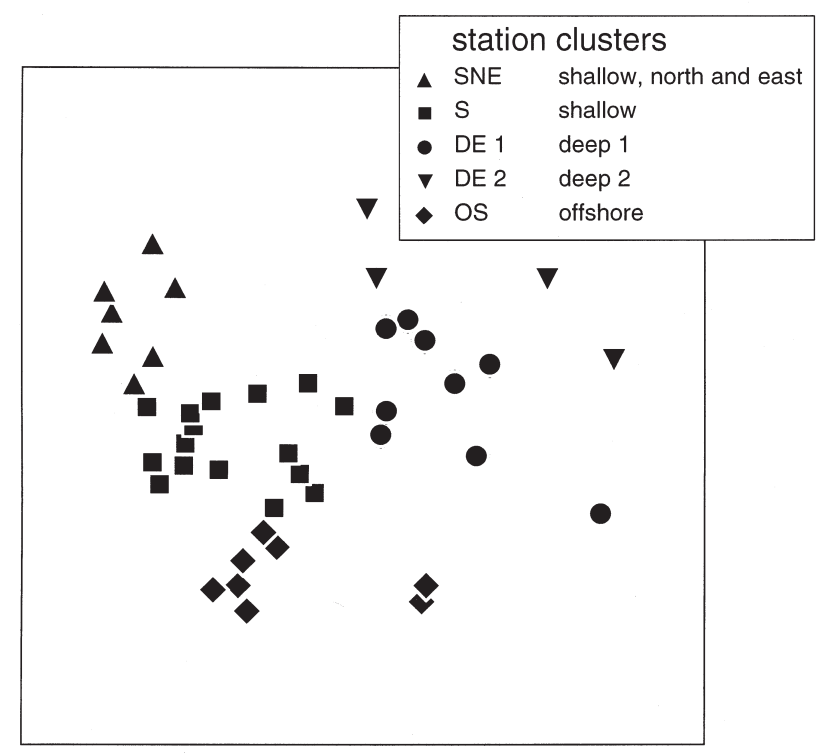

FIG. 3. - MDS plot; Bray-Curtis index, double square root transformation, stress: 0.22 . Five different assemblages of taxa are represented by different symbols (c.f. Fig. 1) superimposed from the cluster analysis. 
TABLE 2. - Abundances of all mega-epibenthic taxa, investigated by underwater photography for station clusters, with presences and total abundances for the entire area of investigation. Taxa ordered according to result of cluster analysis. Abreviations: ALC (Alcyonaria), ALG (Algae), ANT (Anthozoa), ASC (Ascidiacea), AST (Asteroidea), BIV (Bivalvia), BRA (Brachiopoda), BRY (Bryozoa), CEP (Cephalopoda), CRI (Crinoidea), CRU (Crustacea), DEC (Decapoda), ECN (Echinoidea), ECU (Echiurida), GAS (Gastropoda), GOR (Gorgonaria), HOL (Holothuroidea), HYD (Hydrozoa), ISO (Isopoda), OPH (Ophiuroidea), PEN (Pennatularia), PIS (Pisces), POC (Polychaeta), POP (Polyplacophora), POR (Porifera).

(a) Community table with all taxa used for the community analysis and all other calculations.

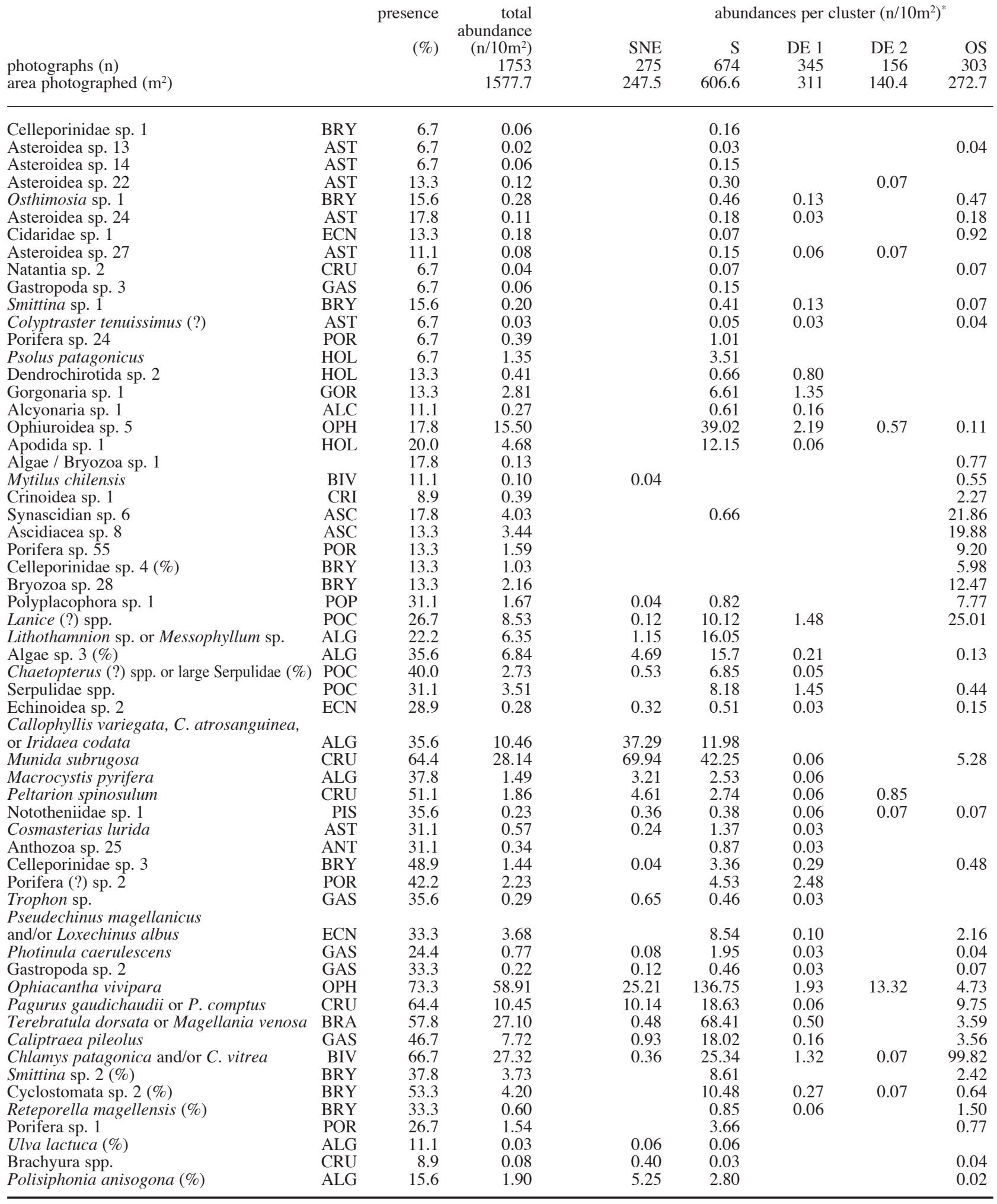


TABLE 2. (Cont.) - Abundances of all mega-epibenthic taxa, investigated by underwater photography for station clusters, with presences and total abundances for the entire area of investigation. Taxa ordered according to result of cluster analysis.

(a) Community table with all taxa used for the community analysis and all other calculations.

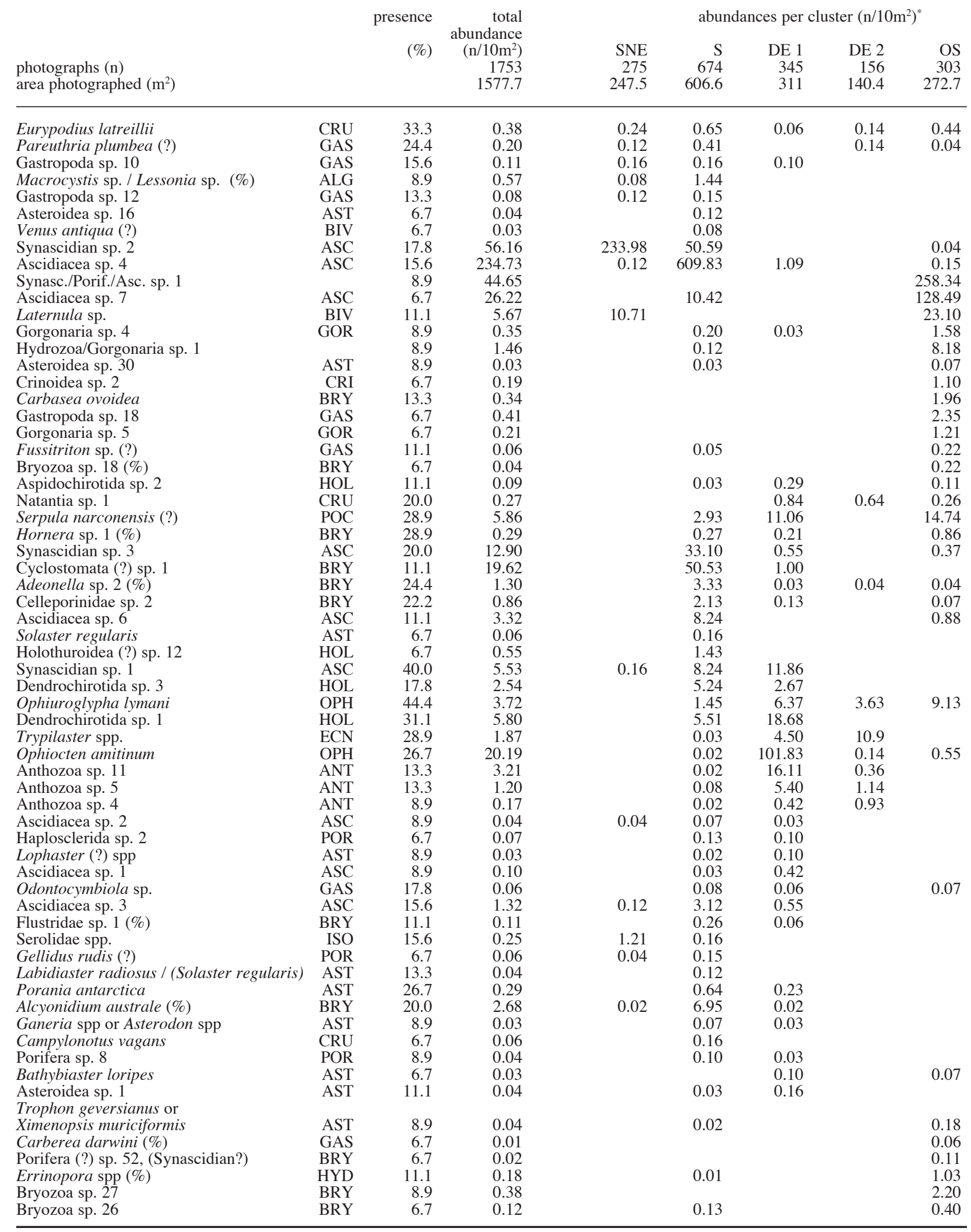


TABLE 2. (Cont.) - Abundances of all mega-epibenthic taxa, investigated by underwater photography for station clusters, with presences and total abundances for the entire area of investigation. Taxa ordered according to result of cluster analysis.

(b) Taxa not used for the community analysis but all other calculations e.g. diversity.

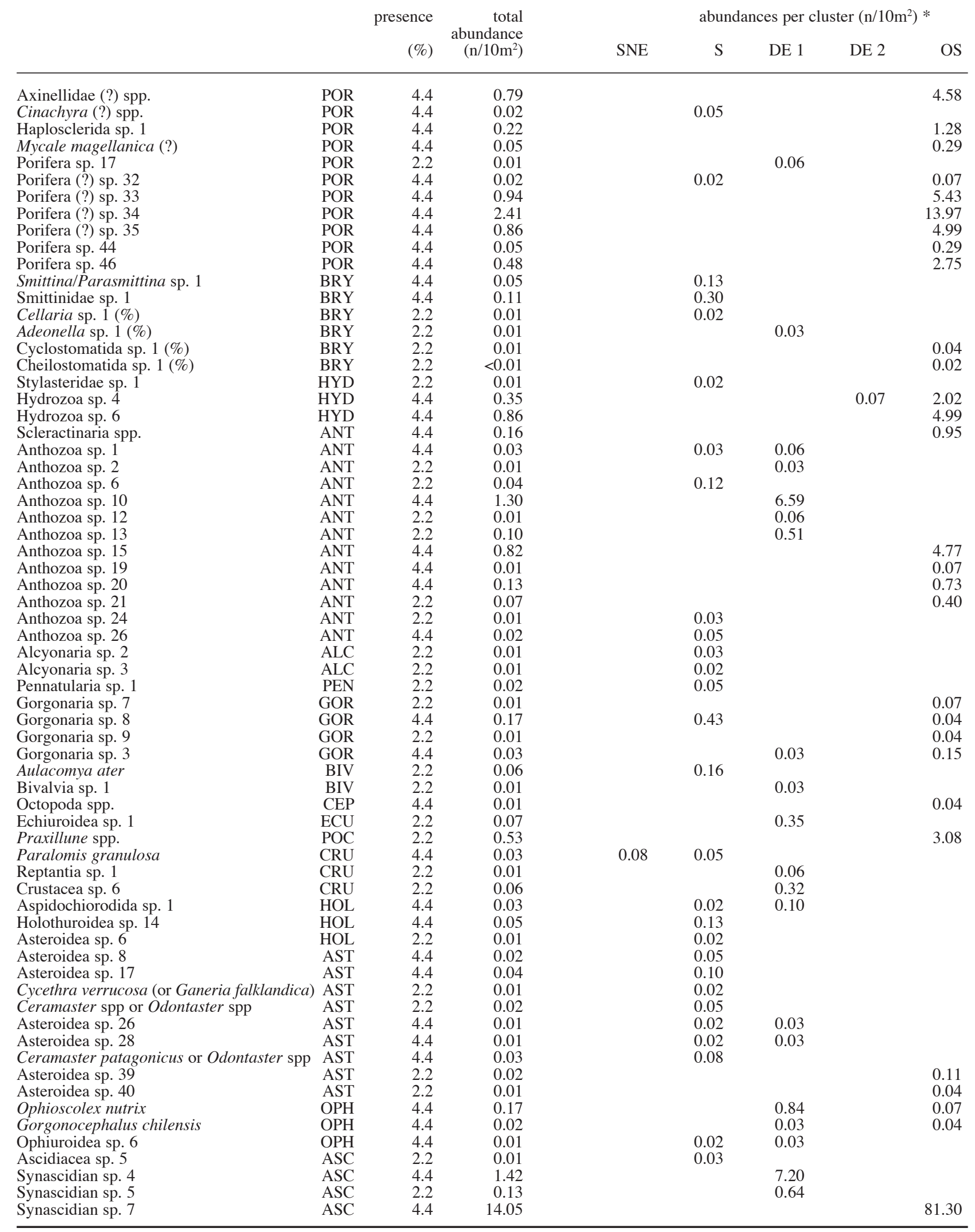


TABLE 2. (Cont.) - Abundances of all mega-epibenthic taxa, investigated by underwater photography for station clusters, with presences and total abundances for the entire area of investigation. Taxa ordered according to result of cluster analysis.

(b) Taxa not used for the community analysis but all other calculations e.g. diversity.

\begin{tabular}{|c|c|c|c|c|c|c|c|c|}
\hline & \multirow{2}{*}{\multicolumn{2}{|c|}{$\begin{array}{r}\text { presence } \\
(\%)\end{array}$}} & \multirow{2}{*}{$\begin{array}{r}\text { total } \\
\text { abundance } \\
\left(\mathrm{n} / 10 \mathrm{~m}^{2}\right)\end{array}$} & \multicolumn{5}{|c|}{ abundances per cluster $\left(\mathrm{n} / 10 \mathrm{~m}^{2}\right) *$} \\
\hline & & & & SNE & $\mathrm{S}$ & DE 1 & DE 2 & OS \\
\hline Synascidian sp. 10 & $\mathrm{ASC}$ & 2.2 & 0.04 & & 0.12 & & & \\
\hline Chondrichthyes sp. 1 (unknown for the area) & PIS & 4.4 & 0.01 & & 0.02 & 0.03 & & \\
\hline Congiopodus peruvianus & PIS & 2.2 & 0.01 & & & 0.03 & & \\
\hline Coelorhinchus fasciatus (?) & PIS & 4.4 & 0.03 & 0.04 & 0.05 & & & \\
\hline Lepidion ensiferus (?) & PIS & 2.2 & 0.01 & & & & & 0.04 \\
\hline Macrouridae sp. 1 & PIS & 2.2 & 0.01 & & & 0.03 & & \\
\hline Myxinidae sp. 1 & PIS & 2.2 & 0.01 & & 0.02 & & & \\
\hline Nototheniidae or Bovichthidae (Cottoperca) & PIS & 2.2 & 0.01 & & 0.02 & & & \\
\hline Rajidae sp. 1 (unknown for the area) & PIS & 2.2 & 0.07 & & 0.18 & & & \\
\hline $\begin{array}{l}\text { Desmarestia confervoides, D. distans, } \\
\text { or D. anceps }(\%)\end{array}$ & ALG & 4.4 & 0.39 & & 1.01 & 0.02 & & \\
\hline Algae sp. 21 & ALG & 2.2 & 2.91 & & 7.58 & & & \\
\hline Algae / Bryozoa sp. 2 & & 2.2 & $<0.01$ & & & & & 0.02 \\
\hline indet. sp. 7 & & 4.4 & 0.02 & & & 0.06 & 0.07 & \\
\hline indet. sp. 12 & & 4.4 & 0.01 & & & & & 0.07 \\
\hline
\end{tabular}

(c) Taxa of coarse identification level, not used for the community analysis and diversity calculation.

\begin{tabular}{|c|c|c|c|c|c|c|c|}
\hline Porifera spp. & 57.8 & 2.39 & 1.41 & 2.18 & 1.90 & & 5.54 \\
\hline Bryozoa spp. (\%) & 31.1 & 0.10 & & 0.09 & 0.02 & & 0.35 \\
\hline Hydrozoa spp. & 6.7 & 0.04 & & & & & 0.26 \\
\hline Anthozoa spp. & 26.7 & 0.30 & & 0.18 & 0.29 & 0.14 & 0.92 \\
\hline Alcyonaria spp. & 2.2 & 0.01 & & 0.02 & & & \\
\hline Gorgonaria spp. & 17.8 & 0.38 & & 0.23 & & 0.07 & 1.65 \\
\hline Gastropoda spp. & 26.7 & 0.15 & 0.04 & 0.18 & & & 0.44 \\
\hline Bivalvia spp. & 6.7 & 0.02 & & 0.03 & & 0.07 & \\
\hline Polychaeta spp. & 15.6 & 0.09 & & 0.10 & 0.13 & & 0.15 \\
\hline Crustacea spp. & 42.2 & 0.22 & 0.24 & 0.28 & 0.03 & 0.07 & 0.33 \\
\hline Pycnogonida spp. & 17.8 & 0.08 & 0.04 & 0.10 & 0.10 & & 0.07 \\
\hline Holothuroidea spp. & 13.3 & 0.05 & & 0.13 & & & \\
\hline Crinoidea spp. & 8.9 & 0.03 & & & & & 0.18 \\
\hline Echinoidea spp. & 13.3 & 0.05 & & 0.05 & & & 0.18 \\
\hline Asteroidea spp & 37.8 & 0.37 & & 0.82 & 0.19 & & 0.07 \\
\hline Ophiuroidea spp. & 26.7 & 0.52 & & 0.46 & 0.19 & 0.07 & 1.72 \\
\hline Ascidiacea spp. & 20.0 & 0.19 & & 0.08 & 0.06 & & 0.84 \\
\hline Synascidians spp. & 15.6 & 0.22 & & 0.05 & & & 1.17 \\
\hline Pisces spp. & 6.7 & 0.02 & & 0.03 & & & 0.04 \\
\hline Algae spp. (\%) & 37.8 & 0.18 & 0.14 & 0.20 & 0.03 & 0.11 & 0.40 \\
\hline indet. spp. & 4.4 & 0.23 & & & & & 1.32 \\
\hline$\sum$ (total) & 100.0 & 768.12 & 415.41 & 1325.08 & 221.06 & 33.83 & 849.92 \\
\hline number of $t$ axa & 234 & & 47 & 161 & 104 & 27 & 127 \\
\hline
\end{tabular}

* Taxa for which no abundances but the cover of the sediment surface was determined are indicated by (\%) after the name of the taxon.

\section{Diversity}

The calculations were based on all organisms identified to the genus and/or species level including rare taxa. The Shannon index (using $\log _{e}$; Shannon and Weaver, 1964) was calculated separately for each station (alpha diversity) and in addition, for the complete set of data of each cluster (overall diversity). High values indicate a combination of many species and an even distribution of the specimens over the species. The evenness was determined by the Pielou index (Pielou, 1977) which is independent from the number of taxa. Values close to the maximum of 1 show uniform abundances of the taxa. The values for the station groups, which result from cluster analysis, were compared by a Wilcoxon test (2-tailed, $\mathrm{p}<0.05$ ).

\section{Relationship between physical and biological data (after Clarke and Ainsworth, 1993)}

Six physical parameters were used for the BIOENV analysis: water depth, abundance of photographs with more than $5 \%$ cover of the sediment by phytodetritus, with soft sediment surface (no structure indicating sandy sediment recognizable on 
the photographs), with sand and gravel (sandy structure with grain size $<1 \mathrm{~cm}$ diameter visible), with more than 10 stones ( $>1 \mathrm{~cm}$ diameter), and with more than $5 \%$ cover of the sediment by biogenic debris. None of these parameters were correlated when tested by pairs $(\mathrm{p}<0.05, \mathrm{r}<0.65)$. Corresponding to the biological similarity matrix between stations (see above) the data set for the physical factors was calculated by the Euclidean distance. Finally, the Spearman rank correlation was calculated between these similarity matrices. Concerning the physical data the calculation was performed for the single parameters and for all their possible combinations.

\section{RESULTS}

A total of 121,202 megabenthic specimens were counted on 1753 underwater photographs from 45 stations. This includes values of the percent cover of the sea-floor by taxa which could not be counted (e.g. bryozoans and algae). A total of 226 taxa were separated. For an additional 10 stations a classification of the species assemblages was possible based on the occurrence of firstly calculated key taxa. Total average abundances, presences with reference to all 45 stations analyzed in detail, and abundances per station cluster are given in Table 2. In Table 2a the stations and taxa are ordered according to the result of the cluster analysis. The 82 taxa listed in Table $2 b$ were additionally used for the diversity calculations but not in the cluster analysis or MDS.
Table 1c contains 21 taxa of a coarse identification level. All species not shown in Fig. 4, but mentioned in the text and in Table 3 (key species), which were not determined, are briefly described in the annex. Due to technical reasons during the analysis the names of a few undetermined species are not consecutively numbered.

\section{Abundances and presences}

Highest abundances per station were found for Ascidiacea sp. $4\left(9570.3 / 10 \mathrm{~m}^{2}\right.$, stn 1219 and $698.9 / 10 \mathrm{~m}^{2}$, stn 1312), synascidian sp. 1 $\left(1572.2 / 10 \mathrm{~m}^{2}\right.$, stn 1167 and $685.3 / 10 \mathrm{~m}^{2}$, stn 1219$)$, the brittle star Ophiacantha vivipara $\left(1273.3 / 10 \mathrm{~m}^{2}\right.$, stn B), and the bryozoan Cyclostomata (?) sp. 1 $\left(888.0 / 10 \mathrm{~m}^{2}\right.$, stn 1239). In the total area of investigation the decapod crustacean Munida subrugosa, the brachiopod(s) Terebratula dorsata / Magellania venosa, the bivalve(s) Chlamys patagonica / C. vitrea, Ascidiacea sp. 7 and the brittle star Ophiocten amitinum had abundances $>20 / 10 \mathrm{~m}^{2}$ (Table 1) in addition to the above mentioned taxa. However, $74 \%$ of all taxa were rare $\left(<1 / 10 \mathrm{~m}^{2}\right)$ and $44 \%$ were very rare $\left(<0,1 / 10 \mathrm{~m}^{2}\right)$. Taxa with highest presence values (found at $>60 \%$ of all stations) were $O$. vivipara, Chlamys patagonica / C. vitrea, $M$. subrugosa, and the hermit crabs Pagurus gaudichaudii and/or $P$. comptus whereas $56 \%$ had low presences $(<10 \%)$. Highest abundances for all taxa $\left(>2000 / 10 \mathrm{~m}^{2}\right)$ were counted at station 1219 (eastern entrance of Beagle Channel), station 112A (offshore), station B (Beagle

TABLE 3. - Key taxa which serve as discriminators between one cluster and the rest of the stations (according to Clarke, 1993).

\begin{tabular}{|c|c|c|c|c|c|c|}
\hline taxa & & cluster & $\begin{array}{l}\text { averaged abundance } \\
\text { within the cluster }\end{array}$ & $\begin{array}{l}\text { averaged abundance } \\
\text { outside the cluster }\end{array}$ & $\frac{\mathrm{d}_{\mathrm{i}}}{\text { average dissimilarity }}$ & $\mathrm{d}_{\mathrm{i}} / \mathrm{SD}\left(\mathrm{d}_{\mathrm{i}}\right)$ \\
\hline Peltarion spinosulum & (CRU) & SNE & 4.63 & 1.32 & 2.12 & 1.31 \\
\hline Munida subrugosa & (CRU) & SNE & 70.46 & 19.93 & 4.36 & 1.22 \\
\hline Porifera (?) sp. 2 & (POR) & $\mathrm{S}$ & 4.52 & 0.77 & 1.56 & 1.51 \\
\hline Anthozoa sp. 25 & (ANT) & $\mathrm{S}$ & 0.88 & 0.01 & 1.05 & 1.49 \\
\hline Celleporinidae sp. 3 & (BRY) & $\mathrm{S}$ & 3.37 & 0.25 & 1.39 & 1.46 \\
\hline Cosmasterias lurida & (AST) & S & 1.39 & 0.07 & 1.01 & 1.27 \\
\hline Ophiuroglypha lymani & $(\mathrm{OPH})$ & DE 1 & 5.83 & 1.40 & 2.34 & 1.50 \\
\hline Trypilaster $\mathrm{spp}$. & $(\mathrm{ECN})$ & DE 1 & 4.50 & 1.25 & 2.05 & 1.17 \\
\hline Dendrochirotida sp. 1 & (HOL) & DE 1 & 18.12 & 2.67 & 2.61 & 1.14 \\
\hline Trypilaster spp. & $(\mathrm{ECN})$ & DE 2 & 11.10 & 1.00 & 3.80 & 1.66 \\
\hline Algae / Bryozoa sp. 1 & & OS & 0.79 & 0.00 & 1.27 & 3.54 \\
\hline Bryozoa sp. 28 & (BRY) & OS & 12.50 & 0.00 & 2.12 & 1.51 \\
\hline Synascidian sp. 6 & (ASC) & OS & 22.32 & 0.32 & 2.39 & 1.50 \\
\hline Celleporinidae sp. 4 & (BRY) & OS & 6.02 & 0.00 & 1.68 & 1.44 \\
\hline Polyplacophora sp. 1 & (POP) & OS & 8.02 & 0.38 & 1.71 & 1.42 \\
\hline Ascidiacea sp. 8 & (ASC) & OS & 20.85 & 0.00 & 2.14 & 1.40 \\
\hline
\end{tabular}



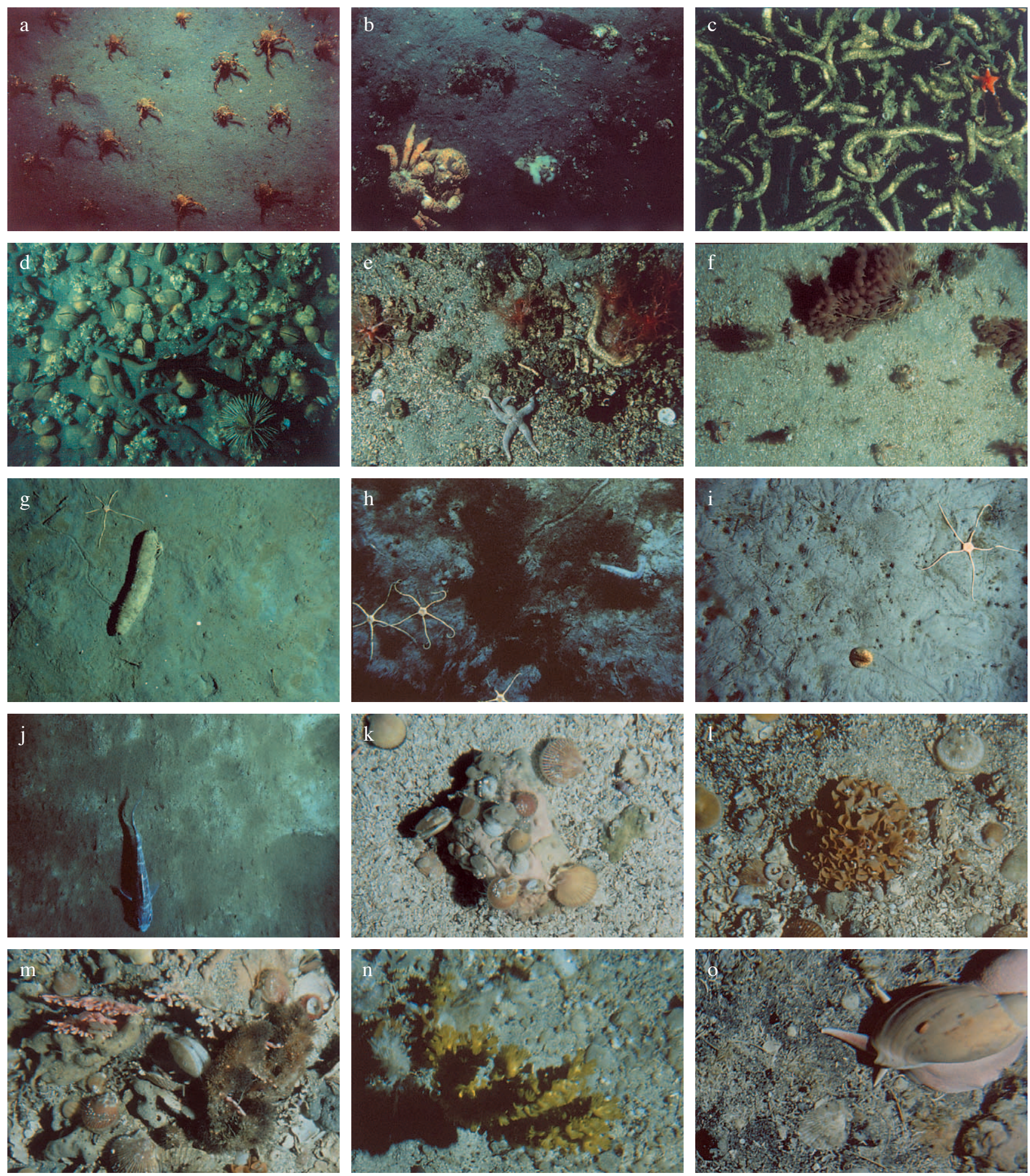

FIG. 4. - Underwater photographs from the Magellan region (area photographed approximately $0.6 \mathrm{~m}^{2}$ ). Fotos: J. Gutt, A. Buschmann, T. Schickan. a) Stn 1148 (SNE), 15 m: Munida subrugosa. b) Stn 1193, 64 m: Paralomis granulosa. c) Stn 880 (S), 56 m: Chaetopterus spp. or large Serpulid, Porania antarctica. d) Stn 927 (S), 40 m: Terebratula dorsata / Magellania venosa, Alcyonidium australe, Echinoidea sp. 2. e) Stn 1035 (S), 45 m: Cosmasterias lurida, Psolus patagonicus. f) Stn 1217 (S), 67 m: Synascidian sp. 2. g) Stn 885 (DE 1), 246 m: Aspidochirotida sp. 1, Reptantia sp. 1 (large), Crustacea sp. 6 (several small specimens, juveniles of Reptantia sp. 1?), Ophiuroglypha lymani. h)Stn 1041 (DE 1), 210 m: Ophiuroglypha lymani, Aspidochirotida sp. 2. i) Stn 1030 (DE 2), 370 m: Trypilaster spp., Ophiuroglypha lymani. j) Stn 1073 (DE 2), 314 m: Coelorhinchus fasciatus (?). k) Stn 110 (OS), 100 m: Bryozoa sp. 28 ( rosate, encrusting), Chlamys patagonica or C. vitrea. 1) Stn 110 (OS): Smittina sp. 2, Chlamys patagonica or C. vitrea. m) Stn 110 (OS): Porifera sp. 45 (left, grey with oscula), Smittina sp. 2 (orange, lower margine), Errinopora spp. (red, branched), Chlamys patagonica or C. vitrea, Pseudechinus magellanicus, Algae/Bryozoa sp. 1 (cushion-shaped, brush-like surface, centre right). n) Stn 112 (OS) 400 m: Gorgonaria sp. 7. o) Stn 113 (OS) 200 m: Odontocymbiola sp., Polyplacophora sp. 1. 
Channel), and station 1293 (Brecknock Channel), lowest values $\left(<40 / 10 \mathrm{~m}^{2}\right)$ were found at stations 1073, 1079, and F (all Beagle Channel).

\section{Community analysis and key taxa}

The stations were grouped into five clusters at a similarity level of 4\%: "shallow, north and east (SNE)", "shallow (S)", "deep 1 (DE 1)", "deep 2 (DE 2)", and "offshore (OS)". This grouping could also be recognized in the MDS plot (Fig. 3). For the taxa 13 clusters were created at the $0 \%$ similarity level. Taxa and stations were ordered in Table 2a according to these results. In Fig. 4, some examples are presented for the various clusters and key species.

In station cluster SNE, synascidians were most common followed by crustaceans (Fig. 5a), to which both best discriminator species, Peltarion spinosulum and Munida subrugosa belonged (Table 3). The latter species reached even higher abundances at a few stations of cluster $\mathrm{S}$, however, it was much more evenly distributed in cluster SNE. On a coarse taxonomic level these two clusters have a similar composition although in cluster $\mathrm{S}$ the solitary and in cluster SNE the compound ascidians were dominant. On the other hand the key taxa of cluster S differed totally: one sponge (?), one anthozoan, one bryozoan, and the asteroid Cosmasterias lurida. The average abundances were less than half in cluster SNE compared with cluster $\mathrm{S}$ which included one extremely high value of $10,650 / 10 \mathrm{~m}^{2}$ (Fig. 6). The two deep clusters, DE 1 and DE 2 were dominated by echinoderms with a considerable percentage of holothurians in cluster DE 1 and of echinoids in cluster DE 2. For DE 1 three taxa from three different classes of echinoderms turned out to be the best key taxa: Ophiuroglypha lymani (Ophiuroidea), Dendrochirotida sp. 1 (Holothuroidea), and Trypilaster spp. (Echinoidea), which was also the only key taxon for cluster DE 2. In terms of total abundance cluster DE 1 was comparable to cluster SNE, and cluster DE 2 was the poorest. In cluster OS the dominant groups were most evenly distributed: synascidians, Ascidiacea, Polychaeta, Bivalvia, Porifera, and Bryozoa. For this cluster the highest number of good key taxa which belonged to a variety of systematic groups were calculated: Algae/Bryozoa sp. 1, Bryozoa sp. 28 , Celleporinidae sp. 4, Reteporella magellensis (both Bryozoa), Polyplacophora sp. 1, Ascidiacea sp. 8, and synascidian sp. 6. The median for the abundance was similar to that of cluster $\mathrm{S}$.
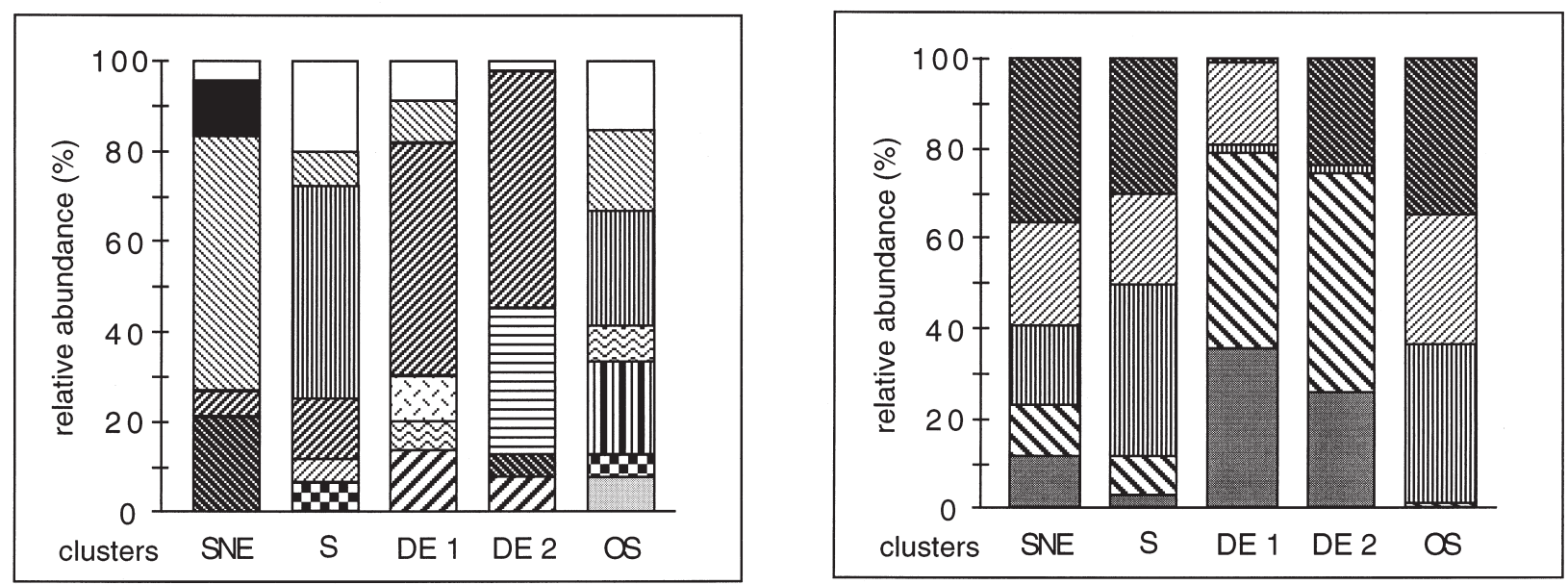

\begin{tabular}{|c|c|c|c|}
\hline & others & & Crustacea \\
\hline & Algae & 8 & Polychaeta \\
\hline & Synascidiacea & W\|ा & Bivalvia \\
\hline |m|⿴囗⿰丿㇄口 & Ascidiacea & $B$ & Anthozoa \\
\hline & Ophiuroidea & $\mathbb{Z}$ & Brachiopoda \\
\hline 㞔 & Echinoidea & DO & Bryozoa \\
\hline 9 & Holothuroidea & E & Porifera \\
\hline
\end{tabular}

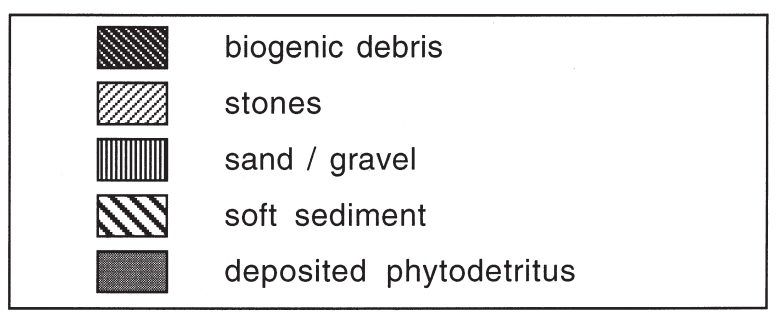

FIG. 5. - Relative abundance (dominance) of higher taxa (left), only values $>5 \%$ per cluster considered, and sediment characteristics (right) for the five assemblages of taxa. 

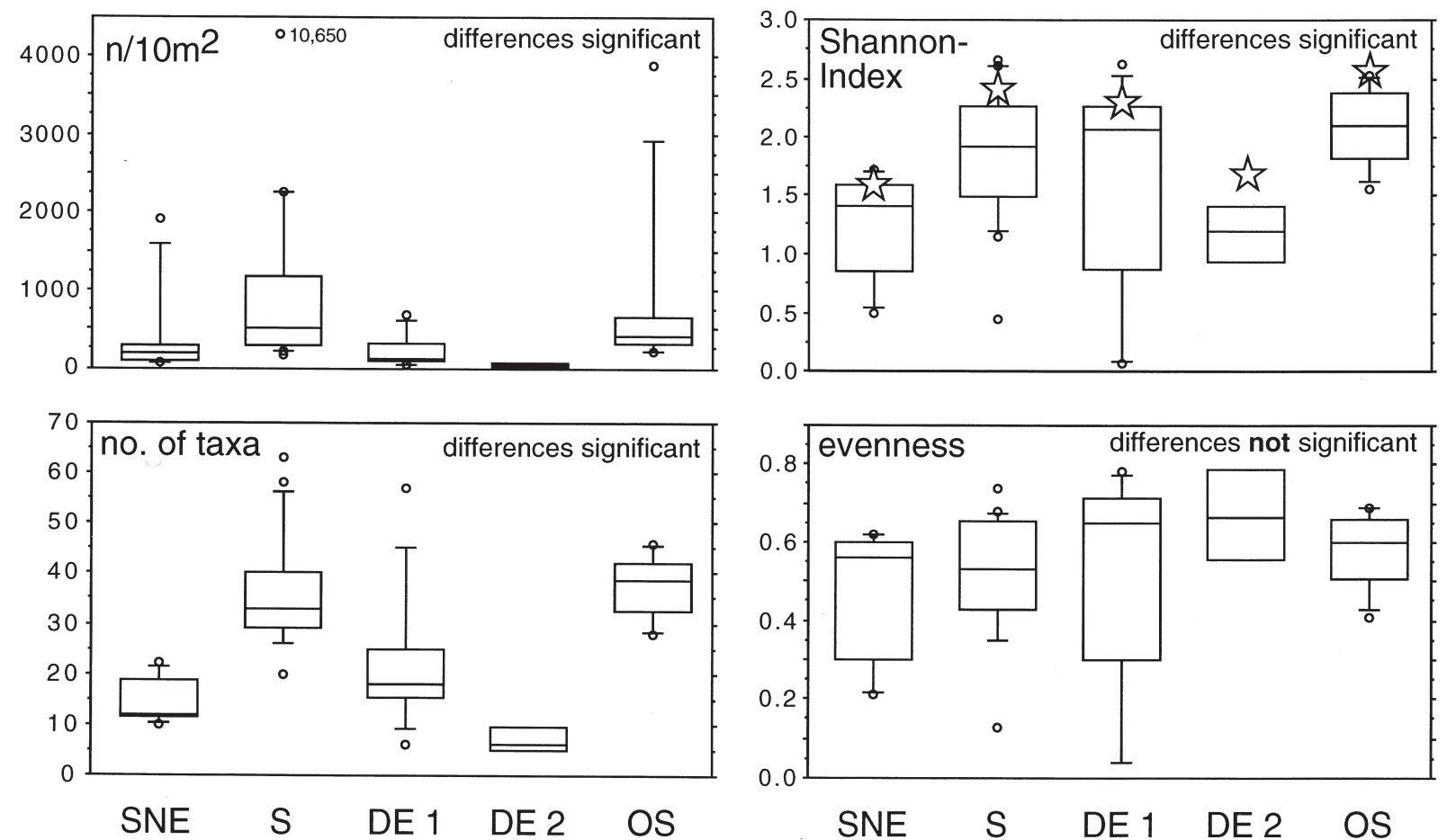

FIG. 6. - Number of taxa, absolute abundance, diversity and evenness for the five assemblages of taxa. Box plots indicate median (central line), $25 \%$ and $75 \%$ percentils (lower and upper line of the box), $10 \%$ and $90 \%$ percentils (lower and upper limit of vertical line), and single values outside the $10 \%$ and $90 \%$ limits (circles). Diversities for the complete data set per station cluster (overall diversity) are shown as stars.

\section{Diversity}

The number of taxa (only those of a fine determination level considered, see Table $2 \mathrm{a}$ and $2 \mathrm{~b}$ ) was highest for the stations of cluster $\mathrm{S}$ and OS with a maximum of 63 taxa at stn 1299 (Fig. 6). Cluster DE 1 performed the widest range (14-57) in this parameter. The other clusters, SNE and DE 2 had less than 25 and 10 taxa per station, respectively. A Kruskal-Wallis test ( $p<0.05,2$-tailed) showed that the numbers of taxa did not belong to one statistical population. Highest diversity values (Shannon index) were calculated also for the clusters S, DE 1, and OS of which again cluster DE 1 had the widest range from 0.07 to 2.63 . The medians for the two other clusters, SNE and DE 2 were between 1.2 and 1.5 , which led to significant differences between the clusters. The evenness values did not differ significantly from each other, however, the highest value was reached by cluster DE 2 which was poorest in abundance, number of taxa and diversity.

\section{Relationship between physical and biological data}

The relative abundance of photographs with the sediment characteristics for the five clusters is shown in Fig. 5b. The relationship between the biological pattern and these physical parameters together with water depth showed the highest correlation coefficient (0.56) when the combination of depth, soft sediment, and debris was considered (Table 3). The same calculation for single physical parameters led to correlation coefficients $\leq 0.51$.

TABLE 4. - Results of the BIOENV analysis (according to Clarke and Ainsworth, 1993). Highest rank-correlation coefficients (r) are listed for relationships between megabenthic distribution and one combination of environmental factors, and single environmental factors indicated by $\mathrm{X}$.

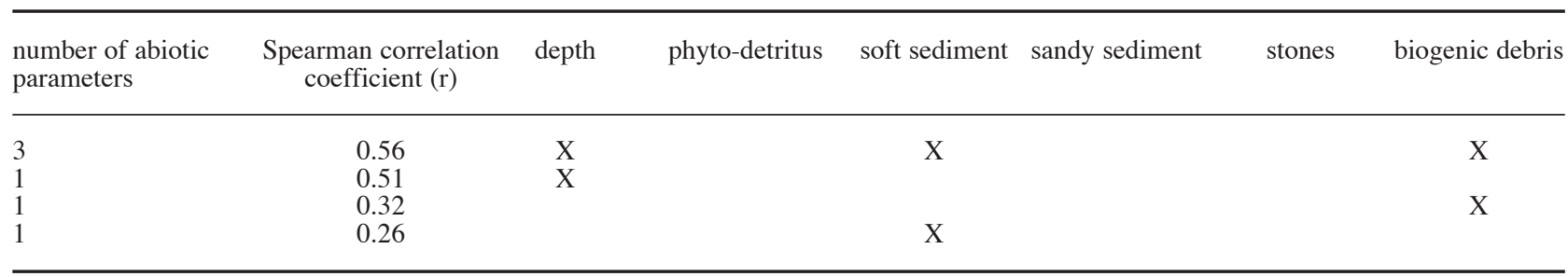




\section{DISCUSSION}

The faunistic and ecological results yielded clear differences in the structure of the mega-epibenthos for the area of investigation. This was obvious for the number and composition of taxa and life forms, e.g. feeding types, their abundance, and diversity. Despite these differences between single stations, the benthos exhibited rather a continuum between different species assemblages than distinct communities which therefore could be classified only with difficulties. As a consequence the hypotheses put forward in the introduction could only be confirmed or rejected based on trends:

The hypothesis that the shallower benthos (clusters SNE and $\mathrm{S}$ ) is more heterogenous than the deeper benthos (clusters DE 1 and DE 2) was not confirmed. For both depth ranges two separate clusters were calculated. If in terms of dominant taxa the shallow stations would differ more from each other than the deeper stations, we would expect a relatively low alpha and a high overall diversity for the shallow stations and similar values for alpha and overall diversity for the deeper stations. Our results showed, however, at each depth level one cluster with an overall diversity being close to the average of the alpha diversity (clusters SNE and DE 1) and one cluster with a slightly higher overall than alpha diversity (clusters S and DE 2). Also the deeper clusters differed considerably in most of the above mentioned structural characteristics. However, there are indications for a more heterogenous benthos in the shallower areas. Firstly, the abundances of the shallow stations showed a broader range than those of the deeper clusters. Secondly, the key species of the clusters SNE and S differed significantly. The benthic assemblage of cluster SNE was characterized by two reptant decapod custaceans: the brachyuran Peltarion spinosulum and the anomuran Munida subrugosa whereas for cluster S one sponge, one anthozoan, one bryozoan, and the asteroid Cosmasterias lurida were calculated to be the best discriminating taxa. For cluster DE 2 only one key taxon, the sea urchins Trypilaster spp. were found, which belonged also to the key taxa of cluster DE 1, where in addition two more echinoderms were determined as key taxa: Ophiuroglypha lymani and Dendrochirodida sp. 1. From this we conclude that cluster DE 2 represented an extremely impoverished fauna of the DE 1 assemblage. Also in the environmental factors some differences within both depth ranges were obvious. The heterogeneity in shallow waters might be the effect of complex environmental processes which led to a more than twofold higher value for sand/gravel in cluster $\mathrm{S}$ than in cluster SNE. The sediments in the deeper clusters differed in the absence of debris and presence of stones in DE 1 and reverse conditions in DE 2. At a few stations in the Paso Ancho investigated by Lorenti and Mariani (1997) the isopod fauna exhibited extreme variations between stations with similar water depths which confirms our general result of a certain heterogeneity independent from water depth.

Stations close to the coast and at slopes represented either by shallow stations in the channel system (clusters $\mathrm{S}$ and SNE) or by the offshore stations close to the continental shelf break (cluster OS), and stations at the bottom of the channels (clusters DE 1 and DE 2) differed considerably. The fauna of the entire depth range between 15 and $430 \mathrm{~m}$ was numerically dominated by filter feeders, mainly by ascidians inside the channel system and, in addition, sponges, polychaetes and bivalves at the offshore stations. Also crustaceans belonged to the most abundant taxa in cluster S, of which one, Munida subrugosa occurred with a relatively high presence also in cluster OS. At the bottom of the channels (clusters DE 1 and DE 2) deposit feeders and omnivorous echinoderms were dominant. One exception concerning dominance and the role as a key taxon is the filter-feeder Dendrochirotida sp. 1, which lives partly infaunally. Also in other regions, e.g. the high Antarctic shelf, such holothurians belong to benthic communities with a poor sessile fauna (Gutt, 1991a; 1991b). Another exception were anthozoans which were relatively more abundant in both deeper clusters than in shallow or offshore areas. Also the sediment characteristics of the offshore cluster OS were more similar to the two shallow (slope) clusters despite the clear difference in water depth. Here the almost total lack of soft sediment and deposited phytodetritus indicates an even higher current velocity than inside the channel system from which the suspension feeders profit most. The amount of phytodetritus may also have been influenced by the different times when the photographs were taken (early summer and autumn, respectively). These results, showing a coarser sediment in the northern Straits of Magellan and the eastern entrance of the Beagle Channel, are in accordance with Brambati et al. (1991) and Colizza (1991). At the bottom of the channel system, in both deeper clusters DE 1 and DE 2, the high abundance of soft sediment and 
deposited phytodetritus indicates a low current velocity at these stations. Differences in current velocity might also be the reason why based on a statistical comparison the benthic structure could be best explained by the combination of the environmental parameters water depth, soft sediment, and biogenic debris. Also Mariani et al. (1996) conclude from their results on polychaetes and isopods in the Straits of Magellan that at a medium spatial scale different environmental situations create a "diversified mosaic of biotopes".

There were only partly differences between the benthos of the narrow Beagle Channel and the wide Straits of Magellan at least on the level of distinction referred to in this paper. In the Beagle Channel we found two assemblages ( $S$ and $\mathrm{DE} 1$ ) which occurred also in the rest of the area of investigation, especially in the Straits of Magellan. The very poor deep cluster (DE 2) was restricted to the Beagle Channel. Two reasons can be assumed for the impoverished epifauna in this cluster: the effect of glaciers with a high input of inorganic particles, and general characteristics at the bottom of such troughs such as a low current velocity, with the consequence of high sedimentation rates of particulate organic matter leading to a dominance of soft sediments. Another hint for the relevance of glaciers for the epibenthos are the two stations directly in front of the Francia glacier which belonged to the poor cluster DE 2 although they were fairly shallow, approx. $100 \mathrm{~m}$. In the narrow and steep Beagle Channel such water depths belong to the slope where in areas without glaciers we found the richest assemblages. A peculiarity of the narrow Beagle Channel was the assemblage of cluster SNE which did not occur in the Straits of Magellan. However, what has been described above as a continuum of different benthic assemblages is here also visible: the dominant high- er taxa of this cluster SNE, compound ascidians and crustaceans, also occurred in the Beagle Channel. Another reason not to assume a distinct benthic composition for the Beagle Channel is the fact that the six stations directly in front of and inside the Seno Garibaldi belonged to three different clusters.

All stations close to the shore and those exposed to the open oceans, e.g. at the eastern and western entrance of the Beagle Channel, belonged to the clusters S and SNE which are also represented inside the entire channel system. Thus, apparently, shallow sills especially in the northeastern part of the Straits of Magellan $(<50 \mathrm{~m})$ do not seem to be a barrier for shallow benthic assemblages, as speculated by Stuardo (1964). On the other hand the two deeper clusters DE 1 and DE 2 from which the offshore stations of cluster OS differed considerably were restricted to the channel system. However, areas close to the shore of comparable depth (100$300 \mathrm{~m}$ ) were not studied by the imaging method.

The benthos inside the channel system did not reveal a greater affinity either to an Atlantic or a Pacific faunistic province or district. This finding is in accordance with a number of zoogeographical classifications summarized by Brattström and Johanssen (1983); e.g. Ekman (1953) described that "At Tierra del Fuego the south Chilean fauna continues immediately into the Patagonian Atlantic fauna which exhibits great similarity with the fauna of the Falklands...". Hedgpeth (1969) came to a similar classification. He established for the entire coastal area from $43^{\circ}$ to $57^{\circ} \mathrm{S}$ the Magellan Province belonging to the Subantarctic region. North of this area Balech (1954), Knox (1960) and Stuardo and Valdovinos (1992) distinguished a Central Chilean and an Argentinian Province. The two latter authors also identified various districts within the Magellan Province (which would seem to be partly in contrast

Table 5. Comparison of the results of this study with those from other shelf regions.

\begin{tabular}{|c|c|c|c|c|}
\hline & $\begin{array}{c}\text { Magellan region } \\
\text { southern South-America } \\
\text { offshore stations } \\
\text { this study }\end{array}$ & $\begin{array}{c}\text { Weddell and Lazarev Seas } \\
\text { Antarctic } \\
3 \text { shallow clusters } \\
\text { Gutt and Starmans (1998) }\end{array}$ & \multicolumn{2}{|c|}{$\begin{array}{c}\text { Northeast Greenland } \\
\text { Arctic } \\
\text { Meyer and Piepenburg (1996) }\end{array}$} \\
\hline $\begin{array}{l}\mathrm{n} / \mathrm{m}^{2} \text { (median) } \\
\text { no. of taxa } \\
\text { diversity (Shannon) }\end{array}$ & $\begin{array}{c}4 \text { (+4 pseudo-replicates) } \\
\text { Ascidiacea } \\
\text { Bivalvia } \\
\text { Porifera } \\
\text { Polychaeta }\end{array}$ & $\begin{array}{c}53(=24+13+6) \\
\text { Bryozoa } \\
\text { Ophiuroidea } \\
\text { Ascidiacea } \\
\text { Holothuroidea } \\
\text { Polychaeta } \\
\text { Ceriantharia } \\
10-75 \\
36-92 \\
1.6-2.5\end{array}$ & $\begin{array}{c}1 \\
\text { Polychaeta } \\
\text { (Ophiuroidea) }\end{array}$ & $\begin{array}{c}1 \\
\text { Ophiuroidea } \\
\text { Crustacea } \\
\text { Polychaeta } \\
\text { Porifera }\end{array}$ \\
\hline
\end{tabular}


to Stuardo (1964) and our results), however, not in the channel system and the southern offshore area referred to in this paper.

A comparison between our findings and those from other regions of the world ocean (Table 5) is only possible if the studies are based on a similar scientific approach, and if geomorphological characteristics as well as the methods are comparable. Our results from the Subantarctic offshore shelf can best be compared with those of Gutt and Starmans (in press) from the high Antarctic Weddell and Lazarev Seas' shelf and two stations of Meyer and Piepenburg (1996) on the northeastern Greenlandic shelf and shelf edge. Despite the extremely varying sampling effort we come to a few general conclusions: In the high Antarctic echinoderms and bryozoans seem to play a more important role in terms of relative abundance at ecologically comparable sampling sites whereas bivalves and sponges were more dominant at the Magellan off-shore stations. Absolute abundances and numbers of taxa can be higher in the Weddell and Lazarev Seas, diversities were found to be similar in the Antarctic and the Magellan region. The fauna off northeastern Greenland seems to be extremely heteogeneous. One station was poor in the number of taxa, and was totally dominated by a dense concentration of polychaetes. A second station was very diverse and had some important taxa which were also dominant in the Magellan region and in the high Antarctic, e.g. ophiuroids, polychaetes, and sponges. A more detailed comparison demands more conformity in the choice of sampling sites and criteria of the analyses.

Summarizing, megabenthic epifaunal communities in the Magellan region exhibit a distinctly patchy distribution which seems to be determined rather by specific medium-scale environmental conditions than by large-scale regional differences.

\section{REFERENCES}

Arntz, W. and M. Gorny. - 1996. Cruise report of the Joint ChileanGerman-Italian Magellan "Victor Hensen" Campaign in 1994. Ber. Polarforsch., 190: 1-113.

Arntz, W., A. Buschmann, K.H. George, D. Gerdes, M. Gorny, M.A. Lardies, K. Linse, A. Montiel, E. Mutschke, M. Rauschert and C. Riós. - 1997. Benthos investigations. In: E. Fahrbach and D. Gerdes (eds.), The expedition ANTARKTIS XIII/4-5 of the research vessel "Polarstern" in 1996. Ber. Polarforsch., 239: $94-97$.

Balech, E. - 1954. División zoogeográfica del litoral sudamericano. Rev. Biol. Mar. Dep. Oceanol. Univ. Chile, 4: 184-195.

Brambati, A., G. Fontolan and U. Simeon. - 1991. Recent sediments and sedimentological processes in the Strait of Magellan. Boll. Oceanol. Teor. Appl., 9: 2-3.

Brattström, H. and A. Johansson. - 1983. Ecological and regional zoogeography of the marine benthic fauna of Chile. Sarsia, 68 : 289-339.

Bray, J.R. and J.T. Curtis. - 1957. An ordination of the upland forest communities of Southern Wisconsin. Ecol. Monogr., 27: 325-349.

Castilla, J.C. - 1985. Food webs and functional aspects of the kelp, Macrocystis pyrifera, community in the Beagle Channel, Chile. In: W. R Siegfried, P. R. Condy and R. M. Laws (eds.), Antarctic Nutrient Cycles and Food Webs, pp. 407-414. Springer, Heidelberg.

Clarke, K.R. - 1993. Non-parametric multivariate analyses of changes in community structure. Aust. J. Ecol., 18: 117-143.

Clarke, K.R. and M. Ainsworth. - 1993. A method of linking multivariate community structure to environmental variables. Mar. Ecol. Prog. Ser., 92: 205-219.

Colizza, E. - 1991. Preliminary report on coastal morphology and sea-bottom sediments of the Channels Beagle, Ballenero, Brecknock, Cockburn, and Magdalena. Boll. Oceanol., 9: 273-279.

Dayton, P.K. - 1985. The structure and regulation of some South American kelp communities. Ecol. Monogr., 55: 447-468.

Ekman, S. - 1953. Zoogeography of the sea. Siedwick and Jackson, London.

Field, J.G., K.R. Clarke and R.M. Warwick. - 1982. A practical strategy for analysing multispecies distribution patterns. Mar. Ecol. Prog. Ser., 8: 37-52.

Gutt, J. - 1991a. On the distribution and ecology of holothurians in the Weddell Sea (Antarctica). Polar Biol., 11: 145-155.

Gutt, J. - 1991b. Are Weddell Sea holothurians typical representatives of the Antarctic benthos? Meeresforsch., 33: 312-329.

Gutt, J. and A. Starmans. - 1998. Structure and biodiversity of megabenthos in the Weddell and Lazarev Seas (Antarctica): ecological role of physical parameters and biological interactions. Polar Biol., 20: 229-247.

Guzmán, L. C. Ríos; M. Ibarra and S. Oyarzún. - 1987. Investigación bancos de ostiones y locos. II. Recurso "ostión" Chlamys (Zygochlamys) patagonica (King \& Broderips). Inf. Inst. Pat. 38: 1-86.

Hedgpeth, J.W. - 1969. Introduction to Antarctic zoogeography. In: V. C. Bushnell and J. W. Hedgpeth (eds.), Distribution of selected groups of marine invertebrates in waters south of $35^{\circ}$ latitude. Antarct. Map Folio Ser., Folio 11: 1-9. American Geographical Society, New York.

Jaramillo, E. - 1981. Ofiuroídeos de los archipiélagos de Chiloé y los Chonos. Stud. Neotrop. Fauna, 16: 113-136.

Knox, G. A. - 1960. Littoral ecology and biogeography of the southern oceans. Proc. R. Soc. London, 152B: 577-624.

Lorenti, M. and S. Mariani. - 1997. Isopod assemblages in the Straits of Magellan: structural and functional aspects. Polar Biol., 18: 154-159.

Mariani, S., M.C. Gambi, M. Lorenti and L. Mazzella. - 1996. Benthic populations of the soft bottoms in the Strait of Magellan (Southern America): Biodiversity, distribution and biogeography of polychaetes and crustacean isopods. Biol. Mar. Medit., 3: $155-158$.

Meyer, M. and D. Piepenburg. - 1996. Epibenthic community patterns on the continental slope off East Greenland at $75^{\circ} \mathrm{N}$. Mar. Ecol. Prog. Ser., 143: 151-164.

Moyano, H. - 1992. Bryozoa de la Expedición Italiana al Estrecho de Magellanes, Febrero - Marzo de 1991: evaluación preliminar. In: V.A. Gallardo, O. Ferretti and H.I. Moyano (eds.), Oceanografía en Antártica, pp. 509-516. Ediciones Documentas, Santiago.

Ojeda, P. and B. Santelices. - 1984. Invertebrate communities in holdfasts of the kelp Macrocystis pyrifera, from Southern Chile. Mar. Ecol. Progr. Ser., 16: 65-73.

Pielou, E.C. - 1977. Mathematical ecology. John Wiley \& Sons, New York.

Retamal, M.A. - 1973. Contribución al conocimiento de los decápodos de la región magallánica. Parte I. Gayana (Zool;), 29: 1-24.

Retamal, M.A. - 1974. Contribución al conocimiento de los decápodos de la región magallánica. Parte II. Gayana (Zool.), 31: 3-23.

Sarà, M. - 1992. I poriferi nell'ecosistema antartico: la Provincia Magellanica. In: V.A Gallardo, O. Ferretti and H.I. Moyano (eds.), Oceanografía en Antártica, pp. 517-522. Ediciones Documentas, Santiago.

Shannon, C.E. and W. Weaver. - 1964. The Mathematical Theory 
of Communication. The University of Illinois Press, Urbana.

Stuardo, J. - 1964. Distribución de los moluscos marinos litorales en Latinoamérica. Bol. Inst. Biol. mar., Mar del Plata, 7: 79-91. Stuardo, J. and C. Valdovinos. - 1992. Barreras, límites faunísticos y provincias biogeoquímicas en Sudamérica austral. In : V. A. Gallardo, O. Ferretti and H. I. Moyano (eds.): Oceanografía en Antártida, pp. 443-451. Ediciones Documentas, Santiago.
Vinuesa, J.H.; L.I. Comoglio and G.A. Lovrich. - 1989. Growth of immature Southern King Crab, Lithodes santolla, in the Beagle Channel. In: Proc. Int. Symp. King \& Tannner Crabs, Anchorage, Nov. 1989, pp. 259-271. Alaska Sea Grant College Program, Fairbanks.

Vinuesa, J.H. - 1991. Biología y pesquería de la centolla (Lithodes santolla). Atlantica, Río Grande, 13: 233-244.

\section{ANNEX}

Short description of unidentified species mentioned in the text, not shown in Fig. 2:

Porifera (?) sp. 2 - white encrusting sponge (?).

Cyclostomata (?) sp. 1 - more or less spheric organisms, white, approx. $1 \mathrm{~cm}$ in diameter.

Celleporinidae sp. 3 - half spheric organisms with cone shaped elevations on surface, no oscula visible.

Bryozoa sp. 29 - colonies 2-7 cm large, white, small specimens almost spheric, larger specimens with very thick and short roundish branches.

Anthozoa sp. 25 - infaunal anthozoans, only the white tentacles $(<20)$ on the sediment surface, size: $<1 \mathrm{~cm}$ in diameter.

Ascidiacea sp. 4 - egg-shaped ascidians, size: approx. $1 \mathrm{~cm}$ in diameter, yellow translucent, incurrent siphon slightly elevated at the upper tip of the body, excurrent siphon close to it, occurring in masses on hard substrata.
Ascidiacea sp. 7 - oval to spheric, white translucent, size: approx. $1 \mathrm{~cm}$ in diameter, incurrent and excurrent siphons not elevated but with a white margine.

Ascidiacea sp. 8 - spheric to oval, yellow translucent, size: approx. $1 \mathrm{~cm}$ in diameter, incurrent and excurrent siphons very slightly elevated.

Synascidian sp. 1 - stalked colony, tulip shaped, translucent grey (in contrast to the orange Synascidian sp. 2), stalks can be branched, total length: approx. $5 \mathrm{~cm}$, stalk $2-5 \mathrm{~mm}$ in diameter, length of stalk approx. twothirds of total length, zooids longitudinally arranged in the body at both sides of a common cloaca channel.

Synascidian sp. 6 - encrusting to cushion shaped greenish grey colonies, "cushions" single or several connected to each other with a slightly conically elevated cloaca opening in centre.

Note: After final submission of the manuscript some doubts arose about the identification of some of the "synascidians". Some structures observed at the seafloor may have been mistakenly classified as "synascidians" when they were, in fact, squid egg cases. This has, however, no influence on the conclusions in this paper. 